\title{
Cownose Ray (Rhinoptera Bonasus) Predation Relative To Bivalve
} Ontogeny

Robert A. Fisher

Virginia Institute of Marine Science

Garrett C. Call

RD Grubbs

Follow this and additional works at: https://scholarworks.wm.edu/vimsarticles

Part of the Marine Biology Commons

\section{Recommended Citation}

Fisher, Robert A.; Call, Garrett C.; and Grubbs, RD, Cownose Ray (Rhinoptera Bonasus) Predation Relative To Bivalve Ontogeny (2011). Journal Of Shellfish Research, 30(1), 187-196.

$10.2983 / 035.030 .0126$

This Article is brought to you for free and open access by the Virginia Institute of Marine Science at W\&M ScholarWorks. It has been accepted for inclusion in VIMS Articles by an authorized administrator of W\&M ScholarWorks. For more information, please contact scholarworks@wm.edu. 


\title{
COWNOSE RAY (RHINOPTERA BONASUS) PREDATION RELATIVE TO BIVALVE ONTOGENY
}

\author{
ROBERT A. FISHER, ${ }^{1 *}$ GARRETT C. CALL ${ }^{1}$ AND R. DEAN GRUBBS ${ }^{2}$ \\ ${ }^{1}$ Virginia Institute of Marine Science, College of William and Mary, PO Box 1346, Gloucester Point, VA \\ 23062; ${ }^{2}$ Florida State University Coastal and Marine Laboratory, 3618 Hwy 98, St. Teresa, FL 32358
}

\begin{abstract}
The purpose of this study was to determine the ability of the cownose ray, Rhinoptera bonasus (Mitchill, 1815), to manipulate oysters and clams, to test for relative prey preference, and to investigate whether susceptibility to cownose ray predation changes with bivalve ontogeny. We investigated patterns of predation for captive adult and young-of-year cownose rays on 4 species of bivalves, including Crassostrea virginica (Gmelin, 1791), Crassostrea ariakensis (Fujita, 1913), Mercenaria mercenaria (Linnaeus, 1758), and Mya arenaria Linnaeus, 1758. In oyster (C. virginica) trials, predation probabilities by adult rays were highest at shell heights of 30-70 $\mathrm{mm}$ and shell depths of 8-22 $\mathrm{mm}$. The rates of predation by adult rays in trials in which samesize oysters were used were higher than rates in most comingled trials. Adult rays showed no differences in predation between native oysters $(C$. virginica) and nonnative oysters ( $C$. ariakensis; $P>0.05$ ). Adult rays selected hard- and soft-shell clams (ManlyChesson index M. mercenaria, $\alpha=0.736 \pm 0.002$, electivity $=0.473 \pm 0.007 ; M$. arenaria,$\alpha=0.742 \pm 0.003$, electivity $=0.485 \pm$ 0.013 ) over oysters $(C$. virginica, $\alpha=0.263 \pm 0.002$, electivity $=-0.473 \pm 0.007 ; \alpha=0.257 \pm 0.003$, electivity $=-0.485 \pm 0.003)$. In young-of-year feeding trials, oysters with a shell height of $10-35 \mathrm{~mm}$ and a shell depth of 3-12 $\mathrm{mm}$ had the highest probability of predation. Native oyster and hard clam peak force or load crush tests resulted in forces of 200-1,500 N and 400-1,400 N across shell depths of 10-35 mm and 21-34 mm, respectively, before valve failure. The results of this study indicate that cownose ray predation on shellfish is limited by shell size and is likely related to ray jaw gape and bite force.
\end{abstract}

KEY WORDS: Durophagy, cownose ray, prey selection, predation risk, Rhinoptera, bivalve mollusc

\section{INTRODUCTION}

The cownose ray, Rhinoptera bonasus (Mitchill, 1815), is a member of the order Myliobatiformes, which includes 10 families of stingrays. Cownose rays (Rhinopteridae) include at least 7 species (Compagno 2005) of coastal pelagic rays that often travel in large schools. $R$. bonasus is the only species that occurs along the east coast of the United States, and is distributed from southern New England to Brazil and throughout the Gulf of Mexico. Cownose rays undergo long seasonal migrations similar to those exhibited by most coastal sharks (Smith \& Merriner 1987, Grusha 2005). In spring, they migrate north, reaching the Outer Banks of North Carolina by April and subsequently the Chesapeake Bay in early May (Smith \& Merriner 1987). Cownose rays are abundant in the Chesapeake Bay and its tributaries throughout the summer, occurring at salinities as low as 8 (practical salinity scale) and temperatures from $15-29^{\circ} \mathrm{C}$ (Smith \& Merriner 1987). By early October, most cownose rays have vacated the Chesapeake Bay to begin their southerly migration to wintering areas primarily off the Atlantic coast of Florida (Grusha 2005).

Cownose rays are durophagous (feeding on hard-shelled prey) predators, feeding on molluscs as well as crustaceans and benthic polychaetes. Collins et al. (2007) reported that cownose rays from Charlotte Harbor on the Gulf coast of Florida fed primarily on small crustaceans (cumaceans) and sedentary polychaetes, but most earlier studies reported that the dominant prey are small, weak-shelled bivalves (e.g., Smith \& Merriner 1985, Blaylock 1993). Concerns over predation on commercial bivalve resources have been raised by fishery and aquaculture operations for many years and in several regions of the world. However, little evidence of actual predation on these resources

*Corresponding author. E-mail: rfisher@vims.edu DOI: $10.2983 / 035.030 .0126$ has been documented (Gray et al. 1997), and studies have shown the general absence of oysters in the diets of rhinopterid and myliobatid rays (Smith \& Merriner 1985, Collins et al. 2007) even when associated with oyster beds (Gray et al. 1997). The ability of cownose rays to feed on large oysters is also questionable as a result of the gape limitations of these rays (Summers 2000, Sasko et al. 2006) and the force required to crush Eastern oysters (Bishop \& Peterson 2006). However, Peterson et al. (2001), report that cownose rays in North Carolina are capable of depleting dense patches of weaker shelled bay scallops (Argopecten irradians (Lamarck, 1819)). Oyster restoration and commercial grow-out efforts in Virginia have undoubtedly experienced setbacks because of cownose rays consuming deployed oysters on experimental reefs and commercial grounds. In 2004 and 2006, 1.2 million and 775,500 oysters were seeded for reef restoration in Virginia, respectively. Wesson (2009) reported that $95 \%$ were eaten by cownose rays. Of the 9 species of batoids that inhabit the Chesapeake Bay during summer months, only 2 species - the cownose ray and the bullnose ray (Myliobatis freminvillii Leseur, 1824) — have grinding plates and jaw musculature potentially capable of manipulating and crushing oysters and hard clams (Mercenaria mercenaria (Linnaeus, 1758)). Although the bullnose rays may be capable of manipulating and crushing adult oysters and hard clams, they are relatively uncommon in Virginia waters, are generally solitary, and are therefore unlikely to be major predators on bivalves in this region. Cownose rays, in contrast, are extremely abundant in the Chesapeake Bay. The reports of cownose ray predation on commercial bivalves coupled with questionable claims of dramatic increases in the cownose ray population coastwide (Myers et al. 2007) have spurred interest in developing a commercial fishery for cownose rays or at least identifying nonlethal deterrents for keeping cownose rays from commercial beds.

Cownose rays use several behaviors in feeding on benthic prey. Cownose rays excavate invertebrate prey from the substrate 
by using vigorous oscillations of the pectoral fins and by jetting water taken in through the spiracles during respiration from the mouth to separate prey further from sediment (Schwartz 1967, Sasko 2000). Inertial suction feeding moves prey from the sediment into the mouth. Anterior expansions of the pectoral fins form two mobile cephalic lobes in cownose rays. These lobes aid in the creation of feeding depressions in the substrate as they are rhythmically but asynchronously extended ventrally, and retracted during feeding (Sasko et al. 2006). The lobes may also serve in increasing suction strength by surrounding identified prey, thereby creating a confined vacuum against the substrate (Fisher, pers. obs.). When not actively feeding, these lobes are retracted and held tight against the body to increase hydrodynamic efficiency.

The jaws of cownose rays also are modified for durophagy. The jaws of sharks and rays consist of 4 primary cartilages: 2 in the upper jaw and 2 in the lower jaw. The symphyses that loosely connect the two sides of the mandible (lower jaw) and of the palatoquadrate (upper jaw) are fused in the rhinopterid and closely related myliobatid rays (Summers 2000). Hyperdeveloped mandibular adductor and coracomandibular muscles in the jaws (González-Isáis 2003), highly calcified jaws, and hard, pavementlike tooth plates enable cownose rays to feed on prey with hard shells. The tooth plates are interlocked, distributing bite force across the whole jaw rather than on a single point (Maschner 2000). A 60-cm cownose ray is capable of bite forces between $40 \mathrm{~N}$ and $200 \mathrm{~N}$ (Sasko and Maschner in Sasko 2000, Motta 2004). Bishop and Peterson (2006) reported that the force necessary to crush the shell of Eastern oysters (Crassostrea virginica (Gmelin, 1791)) is greater than $200 \mathrm{~N}$ for any with a shell height greater than $30 \mathrm{~mm}$, suggesting that only very small oysters are susceptible to the predation pressure that cownose rays can produce. Interestingly, the force required to crush the Suminoe oyster (Crassostrea ariakensis (Fujita, 1913)) is less than $200 \mathrm{~N}$ at all sizes (Bishop \& Peterson 2006), suggesting that at all life stages, this introduced species may be much more susceptible than native oysters to cownose ray predation.

We performed cownose ray predation experiments with captive rays to determine whether a critical size or feature exists for $C$. virginica and $M$. mercenaria that can limit their susceptibility to predation, and to examine patterns of ray predation on various bivalve species of commercial importance.

\section{METHODS}

Cownose rays are schooling fish (Smith \& Merriner 1985) that are strictly observed naturally foraging and feeding in groups. Therefore, each behavioral experiment comprised a group of 4 adult female rays ranging from a $90-\mathrm{cm}$ disc width (DW) $(12.7 \mathrm{~kg})$ to a $102-\mathrm{cm}$ DW $(20.0 \mathrm{~kg})$, and a maximum jaw gape range of $27-34 \mathrm{~mm}$. For subsequent trials we used cownose rays from the 2009-y class (1.5 mo old) measuring 43 (2.1 $\mathrm{kg})-45 \mathrm{~cm}(2.6 \mathrm{~kg}) \mathrm{DW}$ with a maximum jaw gape of $10-18 \mathrm{~mm}$, referenced as young-of-year (YOY). Jaw gape was measured on fresh, whole, dead rays (concurrent study) at the maximum distance between teeth plates when simultaneously pulling the lower jaw ventrally and posteriorly, and upper jaw ventrally and anteriorly. Rays were caught by commercial fishermen using haul seine gear near Back River, Poquoson Flats, in the lower Chesapeake Bay and transported live to the Virginia Institute of
Marine Science in Gloucester Point, VA. We held adult rays and performed predation trials in an aboveground, oblong fiberglass tank $(3 \times 4.2 \mathrm{~m})$ with sand filter recirculation. Water depth was maintained at $0.6 \mathrm{~m}$. We held YOY ray predation trials in $1.2 \times 2.4-\mathrm{m}$ recirculating tanks with a water depth of $0.6 \mathrm{~m}$.

\section{Behavioral Analysis}

Feeding trials were conducted no more than once per day. Cownose rays were maintained in a less than satiated, but not starved, condition. Daily ration for elasmobranchs, including batoids, ranges from $0.3-4.3 \%$ of body weight per day (Wetherbee \& Cortes 2004). The state of hunger, or maintenance level, was achieved by feeding rays approximately $3 \%$ of their cumulative body weight per day in live oysters (average meat weights from various size oysters were calculated) and freshly killed and dismembered blue crabs. The total weight of bivalves (meat) consumed in most trials in this study did not exceed $3.0 \%$ of the total body weight of the cownose rays. Supplemental posttrial feeding occurred daily when estimated consumption by the rays was less than $3 \%$.

When not feeding, rays schooled counterclockwise around the holding tank, keeping close proximity to each other. Upon initiating each feeding trial, the rays typically made a single "investigatory" pass over the shellfish, and then routinely began preying on the shellfish upon their second pass, within $30-60 \mathrm{sec}$ of shellfish introduction.

At the completion of each trial, predation on shellfish was categorized as successful or unsuccessful. Handling time, or the overall time (effort) expended by rays mouthing, crushing, and successfully consuming various shellfish sizes/types, is not reported in this study (concurrent study by authors). Cases when a bivalve was crushed by the rays and not consumed, but death was certain, were recorded as successful predation as a result of the ecological effect in terms of ray-induced mortality on bivalve populations.

\section{Predation Trials}

We used single (cultchless) oysters (C. virginica and $C$. ariakensis), single hard clams (M. mercenaria), and single soft clams ( $M$. arenaria) for adult predation trials. Specimens of each species were divided into groups. C. virginica included the following shell height ( $\mathrm{SH}$ ) groups: $15-25 \mathrm{~mm}$ (seed oysters), 30-40 mm, 45-55 mm, 60-70 mm, 75-85 mm, and 90-100 mm. C. ariakensis included the following SH groups: $45-55 \mathrm{~mm}, 60$ $70 \mathrm{~mm}$, and $75-85 \mathrm{~mm}$. M. mercenaria used in testing included 30-35 mm (little neck), 40-45 $\mathrm{mm}$, and 50-55 mm (top necks) $\mathrm{SH}$ groups. $M$. arenaria used in testing included the shell width (SW) group of 45-55 mm. Oyster SH was measured as the distance between an oyster's anterior (umbone) and posterior (bill) margin. Oyster width, or shell depth (SD), was also measured for each bivalve used in all trials (Fig. 1), and represented the maximal distance between the outside surfaces of closed valves (left and right valves combined). SW was measured as the maximum distance across a valve perpendicular to $\mathrm{SH}$. SW was compared with $\mathrm{SH}$ in trials using $M$. arenaria because its $\mathrm{SW}$ is similar to $\mathrm{SH}$ in oysters. Trial duration (time allowed for predator-prey interaction) was randomly assigned each testing day. Timing of each trial commenced with the introduction of shellfish into the ray holding tank. After trial time expired, rays were herded to one 


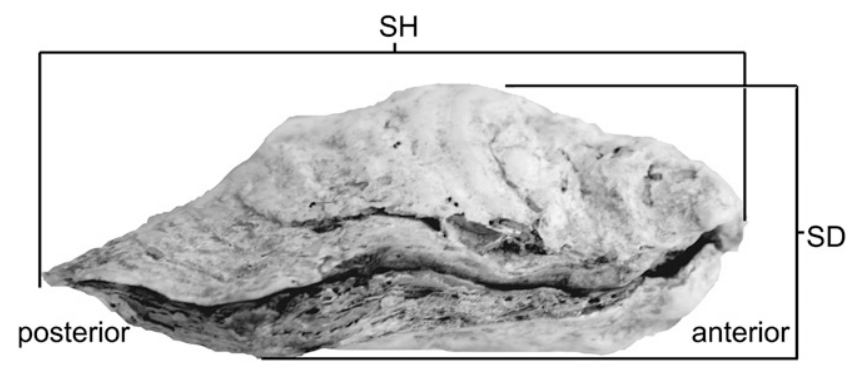

Figure 1. Side view of an oyster $(C$. virginica). SD, shell depth; SH, shell height.

end of the holding tank (opposite end from where prey were introduced) using a fence constructed of PVC that extended the width of the tank. The rays were corralled there until shellfish and crushed shell remnants were collected from the tank bottom. Collection was performed by compiling the shell from the tank bottom using a 1-m long rubber squeegee, followed by scooping shell from the pile with a 2-gal capacity funnel attached with a 1-mm-mesh filter bag. The final removal of small pieces was conducted using a 6-gal wet-dry shop vacuum. Whole bivalves recovered after each trial were sorted from shell remnants, grouped to size or species classification, counted, and remeasured (SH or SW and $\mathrm{SD}$ ).

\section{Comingled Oyster Susceptibility Trials}

To evaluate size preferences, we comingled multiple shellfish size groups together and introduced them simultaneously to the rays. In comingled trials with adult cownose rays, 25 single oysters or clams per SH group (for a total of 150 oysters or 75 clams) were mixed and dumped into the holding tank approximately $1 \mathrm{~m}$ from the tank's vertical end wall, resulting in a mound of randomly mixed bivalves of various sizes covering approximately $0.5 \mathrm{~m}^{2}$. For $C$. virginica, feeding trials were conducted in triplicate for time periods of 7.5, 15, 30, and $45 \mathrm{~min}$, and duplicate for 60-, 120-, 240-min periods. For $C$. ariakensis, we only tested $3 \mathrm{SH}$ groups (because of availability) in triplicate 30 -min trials. Preliminary investigations feeding rays $M$. mercenaria demonstrated that exceeding $15 \mathrm{~min}$ was likely to exhaust the 25 clams in the $30-40-\mathrm{mm}$ SH size class; therefore, clam selectivity trials were only conducted at 15-min durations. For comingled trials with YOY rays, 25 oysters per SH group (SH 10-20 mm, 20-30 mm, and 30-40 mm) were comingled in a 2-gal bucket, then dumped into the holding tank, resulting in a mound $\sim 400 \mathrm{~cm}^{2}$. Triplicate 18 -h feeding trials were conducted.

Data analyses were conducted using SPSS for Windows (version 16.0.0, IBM, Somers, NY). Adult comingled trials were initially evaluated using chi-square tests and $\mathrm{G}$ tests to test the null hypothesis that predation success was equal for bivalves of all SH. In trials in which predation success was unequal, we used the Manly-Chesson alpha index of selectivity for variable prey abundance and normalized it to get electivity ( -1 is complete avoidance and +1 is complete preference) to evaluate prey preferences. Actual count data were standardized to display the proportion of predation based on SH and SD measurements before and after comingled trials. The mortality data collected from these trials were also used to generate proportions of predation. We also used binary logistic regression for both adult and YOY comingled trials to examine the effect of each $\mathrm{SH}$ group, SD, and time period (when appropriate) on predation probability where a binary response-0, alive; 1 , dead-is related to one or more predictor variables. A logistic regression model predicted the probability of predation of 3 different bivalves in the comingled trials - C. virginica, $C$. ariakensis, and $M$. mercenaria - by captive cownose rays. The model can be expressed as

$$
\text { Logit }\{p(x)\}=\log \{p(x) / 1-(x)\}=b_{0}+b_{1} x+b_{2} x_{2}
$$

where $p(x)$ is the probability that a bivalve will be preyed on as a function of a variable $x$, and $b_{0}, b_{1}, b_{2}$ are the regression parameters. The equation can be rearranged to define estimated probability $p(x)$ as

$$
p(x)=\frac{e^{b_{0}+b_{1} x+b_{2} x^{2}}}{\left\{1+e^{b_{0}+b_{1} x+b_{2} x^{2}}\right\}}
$$

Factors $(x)$ contributing to the probability of predation $(p(x))$ included SD and SH groups, and, in one instance, time period for $C$. virginica. For analysis of $C$. virginica, the $\mathrm{SH}$ groups were $15-25,30-40,45-55,60-70,75-85$, and $90-100$ $\mathrm{mm}$. For $C$. ariakensis the SH groups were 45-55, 60-70, and 75-85 mm. The groups for $M$. mercenaria were 30-35, 40-45, and $50-55 \mathrm{~mm}$. We applied this model to each trial for time periods of 7.5, 15, 30, 45, 60, 120, $240 \mathrm{~min}$ for C. virginica; 30 min for C. ariakensis; and $15 \mathrm{~min}$ for M. mercenaria. Time $(x)$ was added as a factor to the model for $C$. virginica to generate a predicted probability across multiple time periods. Parameter estimates for each predictor variable were generated and evaluated for significance $(P<0.05)$. Model fit was evaluated using Hosmer and Lemeshow tests.

\section{Evaluation of Peak Load of C. virginica and M. mercenaria}

Forty oysters (C. virginica: SH, 24-95 mm; SD, 12-35 mm) and 36 hard clams (M. mercenaria: SH, 33-54 mm; SD, 21-31 $\mathrm{mm}$ ) were used to evaluate the force (load) required to crush each species. We used a 100 Kip Enerpac manual hydraulic pump and jack system, connected to a 5,500-lb (25-kN) MTS Systems Corporation (Eden Prairie, MN) load cell (model 661.20B-01). The load cell was connected to a voltmeter through an AC-powered Bridge sensor (model DMD 465WB) for taking load measurements. A standard 0-2-in range deflection dial gauge (with a least count of 0.001 in) was used to record deformation/deflections of the shellfish specimen. Coupling the MTS load cell with the Bridge sensor increased the resolution of the load readings greatly, and the manual hydraulic pump gave precise control over the load increments/intervals. The least applicable load was $0.7 \mathrm{lb}$, or $3 \mathrm{~N}$, with this configuration.

The load cell was calibrated under the MTS load frame system before testing shellfish. The calibration involved the application of a known load to the load cell assembly in increments and the corresponding voltage output recorded. This process establishes the voltage-to-load calibration relationship for the load cell. We weighed and measured SH and SD for all live bivalve samples. Specimens were placed on a solid steel platform under the load cell, and load testing commenced. With all shellfish samples, the load cell was gently brought in 
contact with the specimen, and the deflection dial gauge was set to 0. A small increment of load was then applied using the hydraulic pump, and corresponding deformation of the specimen was recorded from the mechanical dial gauge. This process continued until the specimen failed by crushing. One of the 2 valves of specimens would fail first, at which point load readings were recorded, indicating initial valve failure, or, for the purpose of this study, mortality. Load readings were made at point of first failure (cracking of one valve) and again at point of second valve failure. Load was measured in kilo-Newtons (from the load cell) versus vertical deformation in millimeters (based on the dial gauge readings). Compressive load readings were in pound-force (lbf) with $1 \mathrm{lbf}=4.4482 \mathrm{~N}$.

\section{Comparative Predation Trials}

Adult predation trials were conducted comparing $C$. virginica and $C$. ariakensis, $C$. virginica and $M$. mercenaria, and $C$. virginica and $M$. arenaria. In comparative trials, 25 specimens of both species from the same SH group with similar SD (Table 1) were comingled and simultaneously introduced into the holding tank with 4 adult rays. Trial time was held constant at $15 \mathrm{~min}$ and performed in triplicate. For oyster/soft-shell clam trials, we visually counted mortalities at 3, 5, and $15 \mathrm{~min}$ for triplicate trials. For comparative experiment testing, preference chisquare test or $\mathrm{G}$ tests were performed and combined to test for significant $(\alpha=0.05)$ differences in the numbers of each species preyed on. Independent tests of significance were combined using Fisher's (1954) method. We calculated the Manly-Chesson alpha index of selectivity for variable prey abundance and normalized it to get electivity ( -1 is complete avoidance and +1 is complete preference) (Chesson 1978) to determine prey preference when appropriate.

\section{Rate Trials}

We evaluated size-mediated predation rates by adult rays through predation trials grouping $100 \mathrm{C}$. virginica oysters from a given $\mathrm{SH}$ size over a 15-min period. Rate is defined as the mean number of oyster mortalities per minute per ray within each individual time trial. Duplicate trials were performed for oyster SH: $30-40,45-55,60-70$, and 75-85 mm. Rates of predation were standardized to account for differences in oyster abundance to compare rates of predation with comingled feeding trials during which rays were introduced to oysters of varying sizes.

TABLE 1.

Shellfish used in adult ray predation comparative trials.

\begin{tabular}{llrll}
\hline \hline \multirow{1}{*}{ Trial Type } & \multicolumn{1}{c}{ Species } & $\begin{array}{c}\text { Shell Height } \\
(\mathbf{m m})\end{array}$ & $\begin{array}{c}\text { Mean SD } \\
(\mathbf{m m})\end{array}$ & $\begin{array}{c}\text { SD Range } \\
(\mathbf{m m})\end{array}$ \\
\hline \multirow{2}{*}{ Oyster-oyster } & C. virginica & $75-85$ & 27.1 & $21-32$ \\
& C. ariakensis & $75-85$ & 26.0 & $21-32$ \\
Oyster-oyster & C. virginica & $45-55$ & 16.5 & $17-25$ \\
& C. ariakensis & $45-55$ & 17 & $14-20$ \\
Oyster-hard clam & C. virginica & $45-55$ & 22.9 & $16-32$ \\
& M. mercenaria & $35-40$ & 24.9 & $21-32$ \\
Oyster-soft clam & C. virginica & $45-55$ & 16.0 & $11-24$ \\
& M. arenaria & SW, 45-55 & 16.0 & $11-20$ \\
\hline
\end{tabular}

SD, shell depth; SW, shell width.

\section{RESULTS}

\section{Comingled Trials}

In comingled trials with adult cownose rays, the proportion of oysters successfully eaten increased for all SHs tested as time increased, except for the largest SH class (90-100 mm; Fig. 2A).
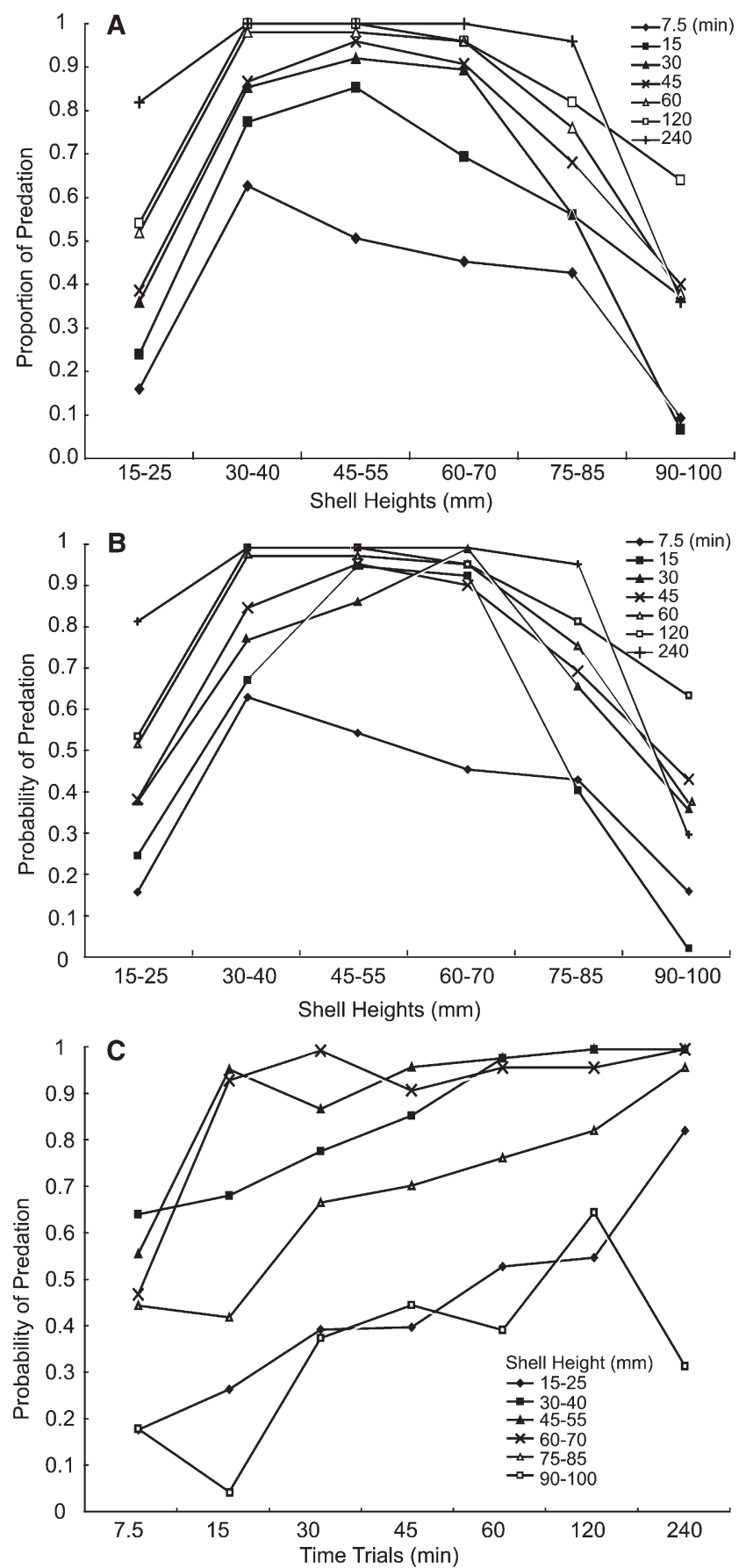

Figure 2. Results from comingled oyster trials with adult cownose rays. (A) Proportion of oysters $(C$. virginica) preyed on for shell height (SH) groups over various time trials based on count data. (B) Mean predicted probabilities of oyster $(C$. virginica) predation for $\mathrm{SH}$ groups from logistic regression model over various time trials. (C) Mean predicted probabilities of predation for oyster $(C$. virginica) SH groups over time. 
Shell heights of $30-40,45-55$, and $60-70 \mathrm{~mm}$ were the most heavily selected for all time trial periods (Table 2). Lowest predation success was observed on 15-25-, 75-85-, and 90100-mm SH oysters.

The probability of predation increased for all shell heights tested as time increased, except for the 75-85- and 90-100-mm oysters in the 15-min time period, and the $90-100$-mm oysters in the 240-min time period (Fig. 2B, C). Overall, oysters in the smallest and largest $\mathrm{SH}$ categories had the lowest selectivity.

Mean SD of oysters within each SH group increased 2-3 mm between pretrial and posttrial in the 60-70-, 75-85-, and 90$100-\mathrm{mm}$ oysters, suggesting selection for those oysters with smaller SD in larger oysters (Table 3). No difference in mean SD was found in the 15-25-, 30-40-, and 45-55-mm SH oysters.
Predation declined with increasing SD. The highest proportion of predation was observed in oysters with SDs between $8 \mathrm{~mm}$ and $22 \mathrm{~mm}$, whereas the lowest predation success was recorded in oysters with SDs greater than $32 \mathrm{~mm}$ (Fig. 3).

The highest probability of predation among bivalves tested was for $C$. virginica in the 8-22-mm SD range, with predation declining with increasing SD (Fig. 4). Probability of predation on C. ariakensis was highest for SDs of 14-20 mm. Similarly, predation declined as SD increased above $22 \mathrm{~mm}$. The highest probability of predation in M. mercenaria was observed on SDs between $21 \mathrm{~mm}$ and $26 \mathrm{~mm}$. A steep decline in predation was observed as SD increased above $26 \mathrm{~mm}$. A logistic regression equation predicted the probabilities of predation for $C$. virginica based on the 8 variables tested (Fig. 4):

TABLE 2.

Combined predation (success or failure) on oysters $(C$. virginica) for adult comingled trials.

\begin{tabular}{|c|c|c|c|c|c|}
\hline Time Trial & Shell Height (mm) & Success & Failure & $\alpha$ & Electivity \\
\hline $7.5 \mathrm{~min}$ & $15-25$ & 12 & 63 & $0.0504 \pm 0.0002$ & $-0.5835 \pm 0.0097$ \\
\hline \multirow{3}{*}{$n=3$} & $30-40$ & 47 & 27 & $0.3193 \pm 0.0057$ & $\mathbf{0 . 3 8 8 7} \pm 0.0232$ \\
\hline & $45-55$ & 38 & 35 & $0.2272 \pm 0.0008$ & $\mathbf{0 . 1 8 7 1} \pm 0.0064$ \\
\hline & $60-70$ & 34 & 40 & $0.1853 \pm 0.0008$ & $\mathbf{0 . 0 6 0 5} \pm 0.0078$ \\
\hline Chi-square $=73.42$ & $75-85$ & 32 & 44 & $0.1945 \pm 0.0156$ & $\mathbf{0 . 0 1 3 9} \pm 0.1880$ \\
\hline$P<0.05$ & $90-100$ & 7 & 67 & $0.0233 \pm 0.0016$ & $-0.8180 \pm 0.0994$ \\
\hline $15 \mathrm{~min}$ & $15-25$ & 18 & 57 & $0.0463 \pm 0.0001$ & $-0.6109 \pm 0.0044$ \\
\hline \multirow[t]{3}{*}{$n=3$} & $30-40$ & 58 & 17 & $0.2637 \pm 0.0072$ & $\mathbf{0 . 2 5 8 4} \pm 0.0513$ \\
\hline & $45-55$ & 64 & 11 & $0.3373 \pm 0.0065$ & $\mathbf{0 . 4 2 1 7} \pm 0.0239$ \\
\hline & $60-70$ & 52 & 24 & $0.1944 \pm 0.0007$ & $\mathbf{0 . 0 9 0 4} \pm 0.0071$ \\
\hline Chi-square $=146.7$ & $75-85$ & 42 & 33 & $0.1461 \pm 0.0039$ & $-0.1072 \pm 0.0781$ \\
\hline$P<0.05$ & $90-100$ & 5 & 70 & $0.0121 \pm 0.0004$ & $-0.8945 \pm 0.0334$ \\
\hline $30 \mathrm{~min}$ & $15-25$ & 27 & 48 & $0.0526 \pm 0.0008$ & $-0.5770 \pm 0.0345$ \\
\hline \multirow[t]{3}{*}{$n=3$} & 30-40 & 64 & 11 & $0.2283 \pm 0.0048$ & $\mathbf{0 . 1 7 5 1} \pm 0.0361$ \\
\hline & $45-55$ & 69 & 6 & $0.2853 \pm 0.0078$ & $\mathbf{0 . 3 1 1 7} \pm 0.0356$ \\
\hline & $60-70$ & 67 & 8 & $0.2741 \pm 0.0076$ & $\mathbf{0 . 2 8 5 2} \pm 0.0404$ \\
\hline Chi-square $=113.8$ & $75-85$ & 42 & 32 & $0.0997 \pm 0.0017$ & $-0.3038 \pm 0.0422$ \\
\hline$P<0.05$ & $90-100$ & 28 & 47 & $0.0616 \pm 0.0034$ & $-0.5559 \pm 0.1637$ \\
\hline $45 \mathrm{~min}$ & $15-25$ & 29 & 46 & $0.0498 \pm 0.0005$ & $-0.5915 \pm 0.0208$ \\
\hline \multirow[t]{3}{*}{$n=3$} & $30-40$ & 65 & 10 & $0.2188 \pm 0.0038$ & $\mathbf{0 . 1 5 2 4} \pm 0.0270$ \\
\hline & $45-55$ & 72 & 4 & $0.3076 \pm 0.0093$ & $\mathbf{0 . 3 5 7 6} \pm 0.0350$ \\
\hline & $60-70$ & 68 & 7 & $0.2374 \pm 0.0013$ & $\mathbf{0 . 2 1 3 0} \pm 0.0087$ \\
\hline $\mathrm{G}=111.9$ & $75-85$ & 51 & 22 & $0.1213 \pm 0.0005$ & $-0.1875 \pm 0.0103$ \\
\hline$P<0.05$ & $90-100$ & 30 & 39 & $0.0652 \pm 0.0035$ & $-0.5313 \pm 0.1522$ \\
\hline $60 \mathrm{~min}$ & $15-25$ & 26 & 24 & $0.0595 \pm 0.0001$ & $-0.5199 \pm 0.0008$ \\
\hline \multirow[t]{3}{*}{$n=2$} & 30-40 & 49 & 1 & $0.2607 \pm 0.0003$ & $\mathbf{0 . 2 7 5 5} \pm 0.0020$ \\
\hline & $45-55$ & 49 & 1 & $0.2607 \pm 0.0003$ & $\mathbf{0 . 2 7 5 5} \pm 0.0020$ \\
\hline & $60-70$ & 48 & 2 & $0.2313 \pm 0.0005$ & $\mathbf{0 . 1 9 9 8} \pm 0.0039$ \\
\hline $\mathrm{G}=101.1$ & $75-85$ & 38 & 12 & $0.1361 \pm 0.0068$ & $-0.1562 \pm 0.1245$ \\
\hline$P<0.05$ & $90-100$ & 19 & 31 & $0.0517 \pm 0.0041$ & $-0.6194 \pm 0.2023$ \\
\hline $120 \mathrm{~min}$ & $15-25$ & 27 & 23 & $0.0615 \pm 0.0005$ & $-0.5117 \pm 0.0204$ \\
\hline \multirow{3}{*}{$n=2$} & $30-40$ & 50 & 0 & $0.2482 \pm 0.0010$ & $\mathbf{0 . 2 4 3 0} \pm 0.0065$ \\
\hline & $45-55$ & 50 & 0 & $0.2482 \pm 0.0010$ & $\mathbf{0 . 2 4 3 0} \pm 0.0065$ \\
\hline & $60-70$ & 48 & 2 & $0.2191 \pm 0.0001$ & $\mathbf{0 . 1 6 7 3} \pm 0.0007$ \\
\hline $\mathrm{G}=78.40$ & $75-85$ & 41 & 9 & $0.1344 \pm 0.0004$ & $-0.1284 \pm 0.0073$ \\
\hline$P<0.05$ & $90-100$ & 32 & 18 & $0.0886 \pm 0.0032$ & $-0.3716 \pm 0.0970$ \\
\hline $240 \mathrm{~min}$ & $15-25$ & 41 & 9 & $0.1281 \pm 0.0035$ & $-0.1734 \pm 0.0679$ \\
\hline \multirow[t]{3}{*}{$n=2$} & 30-40 & 25 & 0 & $0.2174 \pm 0.0001$ & $\mathbf{0 . 1 6 2 9} \pm 0.0001$ \\
\hline & $45-55$ & 50 & 0 & $0.2174 \pm 0.0001$ & $\mathbf{0 . 1 6 2 9} \pm 0.0001$ \\
\hline & $60-70$ & 50 & 0 & $0.2174 \pm 0.0001$ & $\mathbf{0 . 1 6 2 9} \pm 0.0001$ \\
\hline $\mathrm{G}=123.3$ & $75-85$ & 48 & 2 & $0.1941 \pm 0.0120$ & $\mathbf{0 . 0 8 8 5} \pm 0.0120$ \\
\hline$P<0.05$ & $90-100$ & 15 & 35 & $0.0255 \pm 0.0260$ & $-0.7740 \pm 0.0260$ \\
\hline
\end{tabular}

Shell heights in bold type indicate preferred prey items. 
TABLE 3.

Range of shell depths and mean shell depth of $C$. virginica before and after adult ray comingled predation trials.

\begin{tabular}{cccc}
\hline \hline $\begin{array}{c}\text { Shell Height } \\
(\mathbf{m m})\end{array}$ & $\begin{array}{c}\text { Range of Shell } \\
\text { Depth }(\mathbf{m m})\end{array}$ & $\begin{array}{c}\text { Mean Shell } \\
\text { Depth Before } \\
\text { Feeding }(\mathbf{m m})\end{array}$ & $\begin{array}{c}\text { Mean Shell } \\
\text { Depth After } \\
\text { Feeding (mm) }\end{array}$ \\
\hline $15-25$ & $4-9$ & 6 & 6 \\
$30-40$ & $8-18$ & 12 & 12 \\
$45-55$ & $11-22$ & 16 & 16 \\
$60-70$ & $13-33$ & 21 & 24 \\
$75-85$ & $18-35$ & 27 & 29 \\
$90-100$ & $18-40$ & 30 & 32 \\
\hline
\end{tabular}

$p(x)=\frac{1}{1+e^{-\left(7.260+0.013 x_{1}+-0.302 x_{2}+-6.590 x_{3}+-2.574 x_{4}+-0.896 x_{5}+0.457 x_{6}+0.906 x_{7}\right)}}$

where $p(x)$ is Prob $(0,1), x_{1}$ is time, $x_{2}$ is $\mathrm{SD}, x_{3}$ is an $\mathrm{SH}$ of 15 $25 \mathrm{~mm}, x_{4}$ is an SH of $30-40 \mathrm{~mm}, x_{5}$ is an SH of $45-55 \mathrm{~mm}, x_{6}$ is an $\mathrm{SH}$ of $60-70 \mathrm{~mm}$, and $x_{7}$ is and $\mathrm{SH}$ of $75-85 \mathrm{~mm}$. All variables were significant at the 0.05 level, and the Hosmer and Lemeshow Test was nonsignificant $(P>0.108)$, suggesting the model adequately fit the data. Individual analysis of each time trial period resulted in nonsignificant Hosmer and Lemeshow tests for all time periods except for the 15 -min period. Between 3-5 of 7 parameter estimates were significant for each period, but the parameter estimates for SD and the smallest $\mathrm{SH}$ group (15-25 mm) were significant for all time trials (Table 4).

We generated a logistic regression equation for C.ariakensis,

$$
p(x)=\frac{1}{1+e^{-\left(15.329+-0.556_{x 1}+16.421_{x 2}+-0.819_{x 3}\right)}},
$$

where the intercept and SD parameter estimates were significant $(P>0.01)$ and the SH parameter estimates were nonsignificant ( $P>0.998$ and $P>0.472$, respectively). However, the Hosmer and Lemeshow test was significant $(P<0.026)$, suggesting the model did not adequately fit these data. For hard clams $(M$. mercenaria), the logistic regression equation is

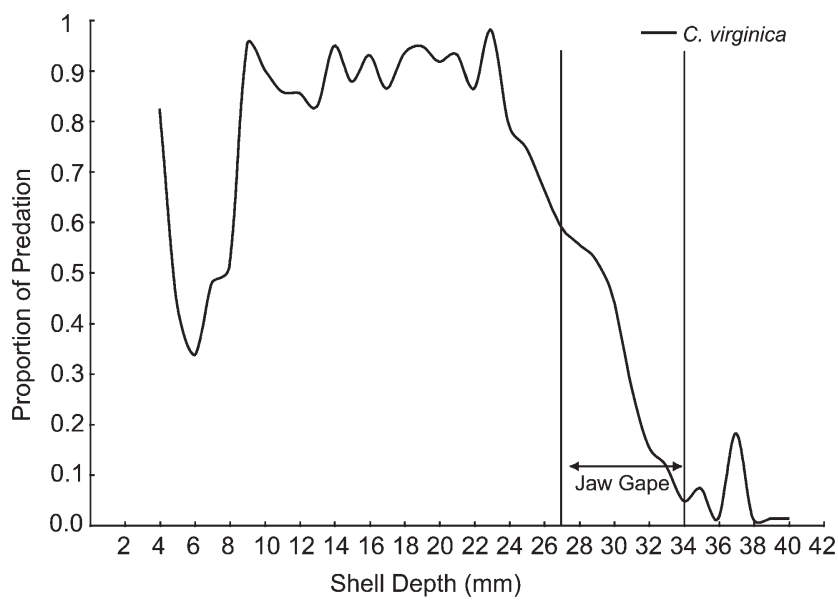

Figure 3. Proportion of $C$. virginica eaten as a function of shell depth in comingled trials. Vertical lines represent the range in maximum jaw gape for adult rays used in predation trials.

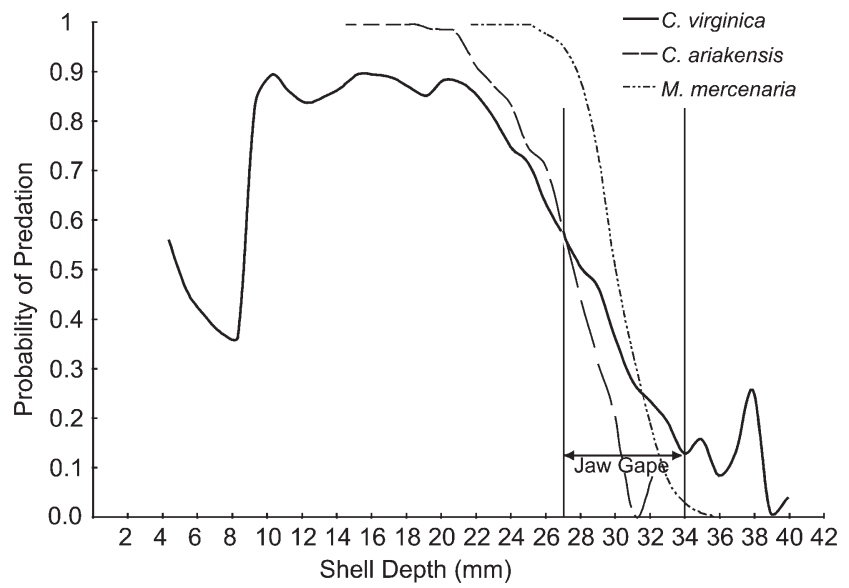

Figure 4. Mean predicted probability of adult ray predation from logistic regression models for $C$. virginica, $C$. ariakensis, and $M$. mercenaria as functions of shell depth. Vertical lines represent the range in maximum jaw gape for adult rays used in predation.

$$
p(x)=\frac{1}{1+e^{-\left(30.355+-0.993_{x 1}+13.944_{x 2}+-0.934_{x 3}\right)}} .
$$

The Hosmer and Lemeshow test was nonsignificant $(P>0.394)$, suggesting a better model fit and, in addition, 2 (intercept and SD; $P<0.12$ and $P<0.05$, respectively) of 4 parameter estimates were significant. Predicted probabilities from the model are shown (Fig. 4).

In comingled trials with YOY rays, the probability of predation declined as SH and SD increased (Fig. 5). The equation generated for YOY predation is

$$
p(x)=\frac{1}{1+e^{-\left(21.027+2.964_{x 1}+-0.370_{x 2}+-0.270_{x 3}\right)}} .
$$

Parameter estimates for intercept and $\mathrm{SH}$ were nonsignificant $(P>0.997, P>0.850$, and $P>0.285)$, whereas the estimate for SD was significant $(P<0.05)$. The Hosmer and Lemeshow test suggested the model did not adequately fit the data $(P<0.049)$.

The force needed to cause failure in one or both valves in $C$. virginica and M. mercenaria increased as SD increased (Figs. 6 and 7). The plot of the log-transformed SD and peak load displays that the load scales isometrically with SD.

For M. mercenaria, linear peak load is lowest at a $21-\mathrm{mm} \mathrm{SD}$ and increases to nearly $1,400 \mathrm{~N}$ at a $33-\mathrm{mm} \mathrm{SD}$ (Fig. 7A). Adult probability of predation and peak load intersect at $30 \mathrm{~mm}$ for $M$. mercenaria. Peak load for $C$. virginica is lowest at an SD of $10 \mathrm{~mm}$ and increases to more than $1 \mathrm{~m} 500 \mathrm{~N}$ at a $35-\mathrm{mm}$ SD (Fig. 7B). Adult probability of predation and peak load intersects at the 29-mm SD for $C$. virginica. YOY predation and linear peak load $(C$. virginica) intersect at a 17-mm SD.

\section{Rate Trials}

The rate of predation for all oyster $\mathrm{SH}$ groups decreased with increasing trial time. In the 7.5-min time trials, 30-40-mm SH oysters were preyed on quickest, followed by the 45-55-, 6070-, then 75-85-mm SH oysters (Fig. 8A). Cownose ray predation rates on oysters were only slightly higher on same-size oysters compared with comingled oysters of varying sizes, except in the 75-85-mm SH (Fig. 8B). 
TABLE 4.

Parameter estimates $\beta_{0} \ldots \beta_{6}$ corresponding to the intercept, shell depth, 5 shell height categories (15-25, 30-40, 45-55, 60-70, and 75-85 $\mathrm{mm}$ ) for individual adult ray comingled trials.

\begin{tabular}{|c|c|c|c|c|c|c|c|c|}
\hline $\begin{array}{c}\text { Time Period } \\
(\mathrm{min})\end{array}$ & Intercept $\left(\boldsymbol{\beta}_{0}\right)$ & $\beta_{1} / \mathbf{p}$ SD & $\beta_{2} / \mathbf{p} 15-25$ & $\beta_{3} / \mathbf{p} 30-40$ & $\beta_{4} / \mathbf{p} 45-55$ & $\beta_{5} / \mathbf{p} 60-70$ & $\beta_{6} / p$ 75-85 & HL \\
\hline \multirow[t]{2}{*}{7.5} & 4.608 & -0.206 & -5.004 & -1.653 & -1.112 & -0.205 & 0.723 & 0.107 \\
\hline & 0.001 & $<0.05$ & $<0.05$ & 0.076 & 0.139 & 0.705 & 0.088 & \\
\hline \multirow[t]{2}{*}{15} & 5.731 & -0.279 & -5.162 & -1.085 & 0.690 & 1.069 & 1.990 & 0.048 \\
\hline & $<0.05$ & $<0.05$ & $<0.05$ & 0.287 & 0.415 & 0.103 & $<0.05$ & \\
\hline \multirow[t]{2}{*}{30} & 9.302 & -0.340 & -7.744 & -3.644 & -1.292 & 1.208 & 0.217 & 0.230 \\
\hline & $<0.05$ & $<0.05$ & $<0.05$ & $<0.05$ & 0.121 & 0.016 & 0.574 & \\
\hline \multirow[t]{2}{*}{45} & 9.144 & -0.325 & -7.546 & -3.531 & -0.458 & 0.594 & 0.492 & 0.202 \\
\hline & $<0.05$ & $<0.05$ & $<0.05$ & 0.001 & 0.614 & 0.288 & 0.225 & \\
\hline \multirow[t]{2}{*}{60} & 10.653 & -0.384 & -8.106 & -2.329 & -0.337 & 0.573 & 0.830 & 0.104 \\
\hline & $<0.05$ & $<0.05$ & $<0.05$ & 0.163 & 0.807 & 0.551 & 0.119 & \\
\hline \multirow[t]{2}{*}{120} & 10.234 & -0.328 & -7.982 & 14.704 & 16.174 & 0.295 & 0.518 & 0.981 \\
\hline & $<0.05$ & $<0.05$ & $<0.05$ & 0.998 & 0.998 & 0.751 & 0.320 & \\
\hline \multirow[t]{2}{*}{240} & 16.638 & -0.554 & -11.569 & 11.780 & 14.131 & 18.154 & 1.927 & 0.997 \\
\hline & $<0.05$ & $<0.05$ & 0.002 & 0.999 & 0.998 & 0.997 & 0.031 & \\
\hline
\end{tabular}

$P$ values of each variable are shown below parameter estimates, and significance level for the Hosmer and Lemeshow tests (HL) of model fit are displayed.

$\mathrm{SD}$, shell depth.

\section{Comparative Trials Between Bivalve Species}

No significant difference in predation was observed between $C$. virginica and $C$. ariakensis in both $\mathrm{SH}$ groups ( $\mathrm{SH} 45-55 \mathrm{~mm}, \mathrm{SH}$ $75-85 \mathrm{~mm} ; P>0.222,0.186$, respectively) tested. Predation success was highest ( $90-96 \%$ eaten) in 45-55-mm oysters of both species. Predation success was significantly higher $(P<0.0001)$ and the rays selected hard clams $(M$. mercenaria, $\alpha=0.736 \pm 0.002$, electivity $=0.473 \pm 0.007$ ) over oysters (C. virginica, $\alpha=0.263 \pm$ 0.002 , electivity $=-0.473 \pm 0.007)$. Rays also selected soft clams, $M$. arenaria at $5 \mathrm{~min}$ into a $15-\mathrm{min}$ trial $(\alpha=0.742 \pm 0.003$, electivity $=0.485 \pm 0.013$ ) over oysters (C. virginica, $\alpha=0.257 \pm$ 0.003 , electivity $=-0.485 \pm 0.003)$ initially, then selection was more equal at the end of 15 -min trial $(M$. arenaria, $\alpha=0.570 \pm$ 0.014 , electivity $=0.141 \pm 0.059$; C. virginica, $\alpha=0.429 \pm 0.014$, electivity $=-0.141 \pm 0.059)$. Although $\mathrm{SH}$ was greater for $C$. virginica in oyster-hard clam trials, mean SD was similar for both species (mean SD of clams, $24.9 \mathrm{~mm}$; mean SD of oysters, $22.9 \mathrm{~mm}$ ).

\section{DISCUSSION}

Observations of cownose rays feeding throughout this study showed that bivalves were viewed as a general food source, and initial selection of potential prey was not based on a prey size. Cownose rays would indiscriminately suck shellfish toward their mouth and, if the shellfish fit between the ray's jaws and adequate crushing force was applied, the shellfish was eaten. If the prey was too large to fit between the biting plates, it was discarded and escaped predation, at least initially.

Shellfish mortality caused by cownose ray predation of particular SH and SD supports the idea that cownose ray jaw morphology has a quantitative gape limitation related to prey size. In general, adult cownose rays in this study were unable to consume bivalves larger than 31-32 mm SD regardless of SH, and YOY rays were not able to consume those larger than 15-16 $\mathrm{mm} \mathrm{SD}$.

Data suggest that rays select oysters of intermediate $\mathrm{SH}$ or SD. During comingled trials, $3 \mathrm{SH}$ groups (30-40, 45-55, 60-70 $\mathrm{mm}$ ) had the highest probability of being eaten by adult rays whereas predation probability on smaller and larger oysters was significantly lower. Adult rays appeared unable to detect shorter (15-25 mm SH) oysters, and ingestion of those sizes was a result of collateral feeding only on smaller oysters in close proximity to larger target oysters. The tallest oysters $(>75 \mathrm{~mm}$ $\mathrm{SH}$ ) were eaten in fewer numbers because they were too big $\mathrm{SH}$ and SD) to be easily manipulated and required more handling time to consume than oysters of smaller $\mathrm{SH}$ and typically shallower SD. Thus, midsize oysters (30-70 mm SH) fit more easily between the rays' jaws, resulting in higher predation. Given longer time to forage, however, successful predation on larger oysters increased. However, predation rates of the largest 2 size classes remained lower than the 3 intermediate size classes regardless of time allowed, further indicating that physical constraints, such as jaw gape, limited predation success.

In comingled trials with YOY rays, the smallest oysters were most susceptible to predation. YOY rays attempted to feed on the largest oysters offered (30-40 mm SH, 15-19 mm SD), but were unsuccessful because of gape limitations.

The logistic regression model was used to determine the effect of SH and SD on predation. Although direct application of this model might not reflect predation in a natural setting with unlimited time, the model does support the generalization that adult cownose rays do not primarily prey upon very small or very large, deeper bivalves.

At nearly all SDs, there was a direct relationship between trial duration and mortality for $C$. virginica. Given more time, rays would continue to manipulate larger oysters that had been attempted earlier in the trial by one or more rays without success. This aggregate crushing effect, combined with increases in feeding time, contributed to the higher amount of predation. Regardless of time, greatest predation success in comingled trials were on oysters 30-70 $\mathrm{mm} \mathrm{SH}$ and 14-20 mm SD. This suggests the rays actively selected oysters of this size range because they are within ray gape limitations. The Manly-Chesson 

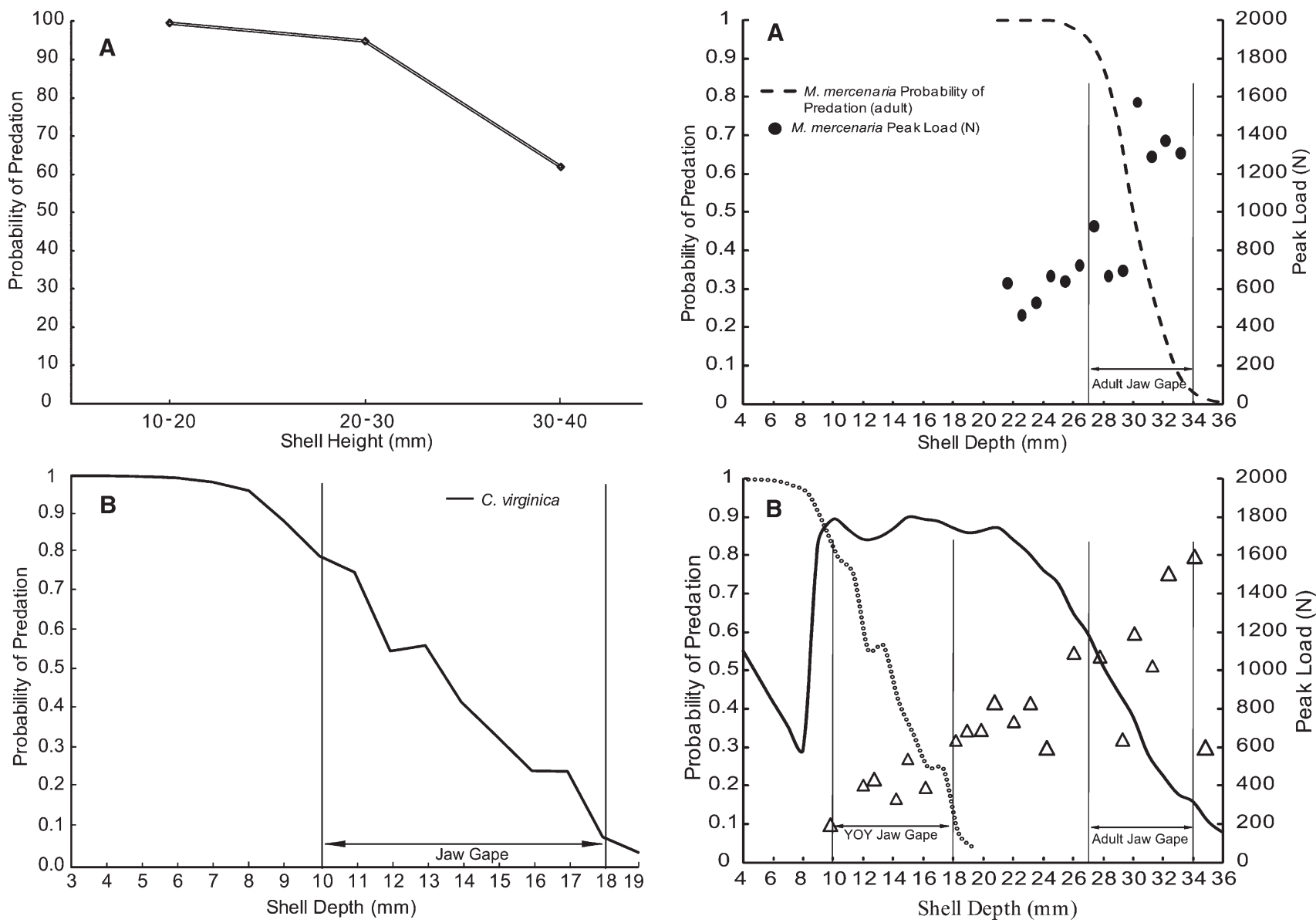

Figure 5. (A) Mean predicted probability of young-of-year (YOY) predation from the logistic regression model for $C$. virginica as related to shell height. (B) Mean predicted probability of YOY predation from the logistic regression model of $C$. virginica as related to shell depth. Vertical lines represent maximum jaw gape range for YOY rays used in predation trials.

index further supports the preference for the aforementioned oyster SHs. These preferences may be further explained by force requirements. The force required to crush bivalves (peak load) was positively correlated with SD and scales isometrically. The rise in force needed to crush a bivalve at increased SD along

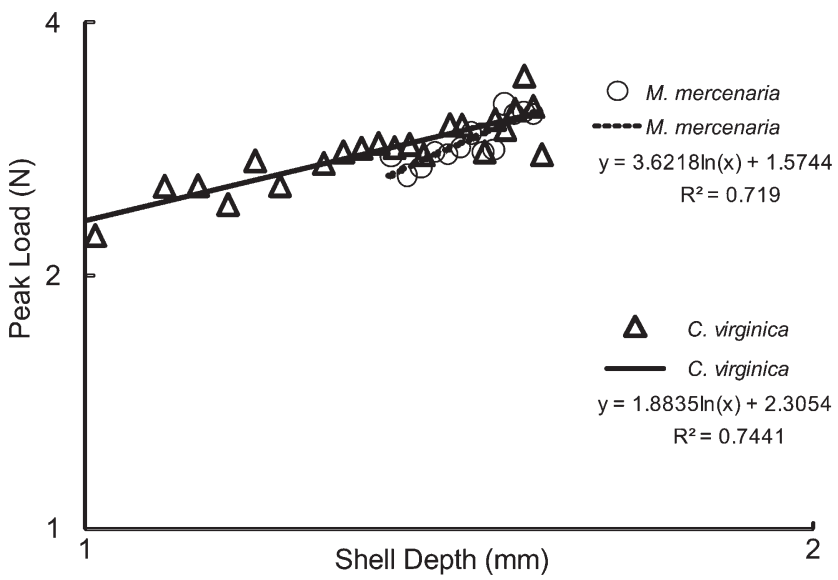

Figure 6. Peak load of $C$. virginica and $M$. mercenaria as related to shell depth plotted on logarithmic axes.

Figure 7. (A) Mean predicted probability, adult ray predation, and nontransformed peak load of $M$. mercenaria as related to shell depth. (B) Mean predicted probability of young-of-year (YOY) adult ray predation and nontransformed peak load of $C$. virginica as related to shell depth. $-C$. virginica Probability of Predation (adult), ${ }^{\ldots} C$. virginica Probability of Predation (YOY), $\Delta C$. virginica Peak Load (N).

with jaw gape and bite force limits may work in concert to lower ontogenetically the susceptibility of bivalves to predation.

Comparing results from comingled versus same-size trials, slightly higher rates of predation were observed in same-size trials except for the 75-85-mm-SH oysters. The difference in the rate of predation may be the result of the greater time required to sort (passively or actively) through oysters of various sizes, including large oysters that cannot be successfully preyed upon at first attempt (75-85 mm). However, the differences in predation rates between trial types may be explained by passive foraging. Adult rays were observed manipulating and preying upon shellfish as they were encountered, regardless of the proximity of more susceptible prey. This passive foraging on oysters was also observed in YOY rays that indiscriminately initiated prey manipulation on the first oyster encountered, regardless of oyster size.

Oyster predation rate in comingled trials declined for each SH category as time increased (Fig. 8A). Rays initially depleted more susceptible prey, resulting in fewer available prey as time progressed. Fewer available prey, a larger proportion of prey approaching or exceeding the gape or bite force limitations (increasing handling time), and satiation resulted in decreasing rates of predation over time. 

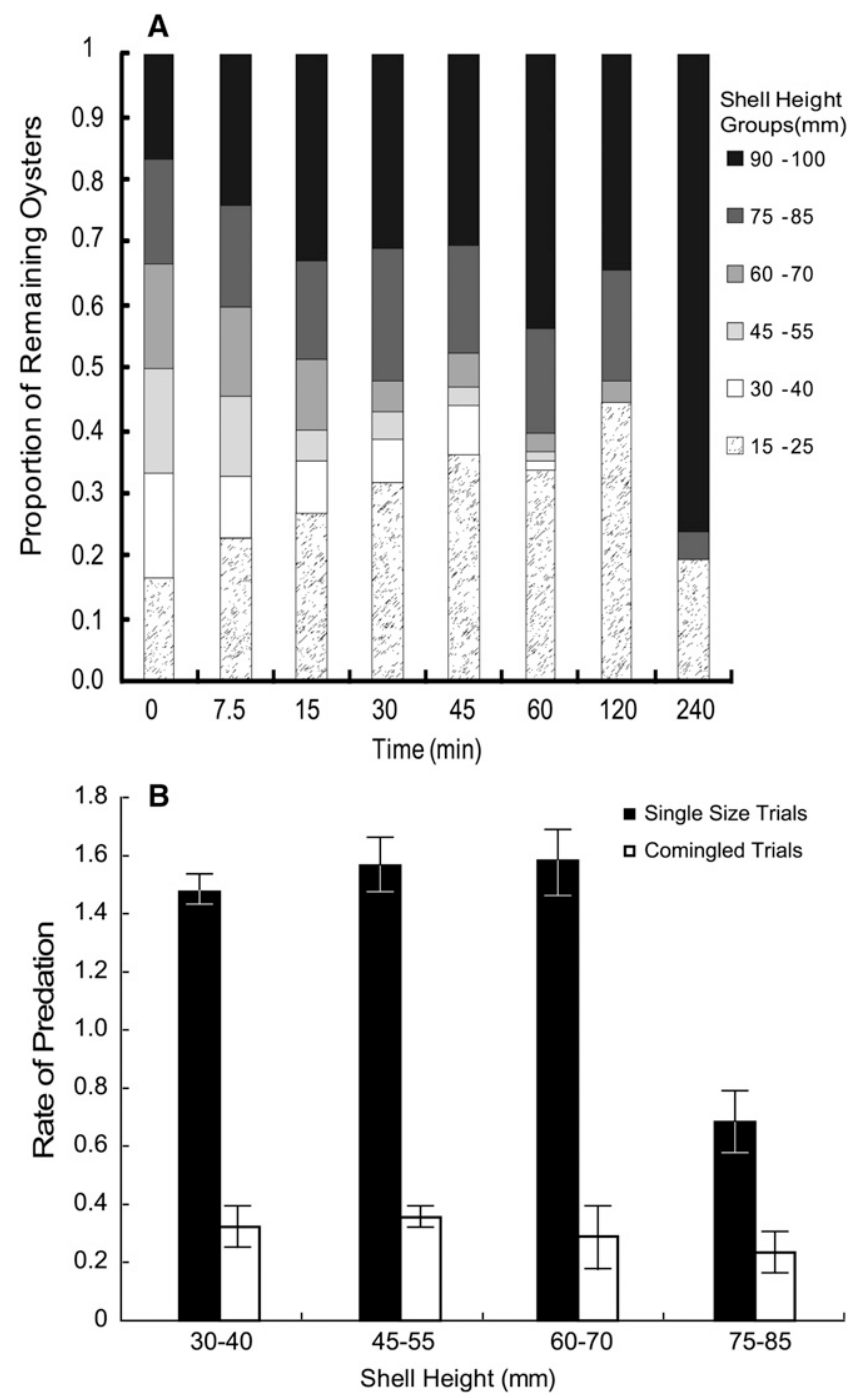

Figure 8. (A) Proportion of remaining oysters after each time period ( $C$. virginica) for comingled trial periods. (B) Mean number of oysters $(C$. virginica) consumed per minute per adult ray for same-size (rate) trials compared with comingled trials. Comingled trial times of 15 min were used for comparison.

\section{Management Implications}

Cownose ray predation on commercial bivalves has been a concern for shellfish industries for more than 40 y (Merriner \& Smith 1979). These concerns are acute in the seeding and growout operations that are part of restoration efforts. Considering that cownose rays have among the slowest reproductive rates of any vertebrate, usually producing a single pup each year (Smith \& Merriner 1986), eradication programs are not a viable solution. However, there may be other means to protect commercial and restored shellfish beds.
Our data suggest cownose rays are gape limited and unable to produce the force needed to crush larger oysters. Therefore, oyster growers and those attempting to seed reefs with mature oysters (broodstock) should consider some measure of protection for shellfish until they reach a shell depth of 22-24 mm and/or breed shellfish able to withstand forces greater than $1,400 \mathrm{~N}$. We demonstrated that YOY rays can successfully prey on seed oysters up to $40 \mathrm{~mm} \mathrm{SH}$. In most aquaculture settings, oyster seed is protected throughout grow-out by various containment methods (bags, floats, racks). However, cultchless oysters are produced for restoration efforts where small oysters are used to seed constructed reefs. In this application, thought should be given to habitat structure, with reefs providing refuge (crevices) for small oysters to settle and be less susceptible to ray predation. Cultched or spat-on-shell oysters have been proposed and used in restoration efforts, and could limit susceptibility of oysters to cownose ray predation. Future work on cownose ray and cultched oyster interaction is needed to evaluate any benefits.

The results also indicate that oyster restoration efforts might not benefit from introducing different oyster species. Our data indicate cownose rays prey on $C$. ariakensis no differently than on $C$. virginica. Although the introduction of the fast-growing $C$. ariakensis has been suggested as a possible solution, the results of comparative predation trials indicate that rays do not discriminate between $C$. ariakensis and $C$. virginica, and therefore the introduction of $C$. ariakensis to the Chesapeake Bay to restore oyster reefs or to revitalize the commercial industry may not be an adequate solution.

Our data suggest cownose rays prefer the clams $M$. mercenaria and $M$. arenaria over the oyster $C$. virginica. Preference for soft clams ( $M$. arenaria) was expected as a result of their high $\mathrm{SH}$-to-SD ratio and relatively weak valves. This species was historically the dominant natural prey of cownose rays in the Chesapeake Bay (Smith \& Merriner 1985); however, natural disaster (Tropical Storm Agnes in 1972), disease, and overexploitation have led to the collapse of soft-shell clam stock in the estuary. Given the significant influence of SD on predation in the comingled trials of $C$. virginica and the similarity of SD in oyster-clam trials, higher predation on hard clams was unexpected. A ray must crush the clam at or near its deepest point (SD), whereas in oysters, rays can "nibble" the flattened, posterior edge of the shells. The ability to handle oysters and apply force along the edges of oysters negates some of the effects of the gape limitation. Further investigation into the amount of nutrition gained by clams over oysters or shell composition and structure could explain the preference.

\section{ACKNOWLEDGMENTS}

This research was funded by the NOAA Chesapeake Bay Office and Virginia Sea Grant College Program. A special thanks to Dr. Jim Kirkley and David Rudders for discussions on statistical analysis, and to Janet Krenn for reviewing drafts of this paper. This is VIMS Contribution \#3146.

\section{LITERATURE CITED}

Bishop, M. J. \& C. H. Peterson. 2006. When $r$-selection may not predict introduced-species proliferation: predation of a nonnative oyster. Ecol. Appl. 16:718-730.
Blaylock, R. A. 1993. Distribution and abundance of cownose rays, Rhinoptera bonasus (Rhinopteridae), in lower Chesapeake Bay, Virginia. Estuaries 16:255-263. 
Chesson, J. 1978. Measuring preference in selective predation. Ecology 59:211-215.

Collins, A. B., M. R. Heupel, R. E. Heuter \& P. J. Motta. 2007. Hard prey specialist or opportunistic generalists? An examination of the diet of the cownose ray, Rhinoptera bonasus. Mar. Freshw. Res. 58:135-144.

Fisher, R. A. 1954. Statistical methods for research workers. Oliver and Boyd.

Compagno, L. J. V. C. 2005. Checklist of living chondrichthyes. In: W. C. Hamlett, editor. Reproductive biology and phylogeny of chondrichthyes: sharks, batoids, and chimaeras. Enfield, NH: Science Publishers. pp. 501-548.

González-Isáis, M. 2003. Anatomical comparison of the cephalic musculature of some members of the superfamily Myliobatoidea (chondrichthyes): implications for evolutionary understanding. Anat. Rec. 271A:259-272.

Gray, A. E., T. J. Mulligan \& R. W. Hannah. 1997. Food habits, occurrence, and population structure of the bat ray, Mylobatis californica, in Humboldt Bay, California. Environ. Biol. Fishes 49: 227-238.

Grusha, D. S. 2005. Investigation into the life history of the cownose ray, Rhinoptera bonasus, (Mitchill 1815). MS thesis, Virginia Institute of Marine Science, College of William and Mary. $115 \mathrm{pp}$.

Maschner, R. P. 2000. Studies of the tooth strength of the Atlantic cownose ray, Rhinoptera bonasus. MS thesis, California State Polytechnic University. 54 pp.

Merriner, J. V. \& J. W. Smith. 1979. A report to the oyster industry of Virginia on the biology and management of the cownose ray (Rhinoptera bonasus, Mitchill) in lower Chesapeake Bay. Spec. Rep. Appl. Mar. Sci. Ocean Eng. 216, 33 pp. Va. Inst. Mar. Sci.

Motta, P. J. 2004. Prey capture behavior and feeding mechanics of elasmobranchs. In: Carrier, J., J. Music \& M. Heithaus, editors. Biology of sharks and their relatives. Boca Raton, FL: CRC Press. pp. 165-202.

Myers, R. A., J. K. Baum, T. D. Shepherd, S. P. Powers \& C. H. Peterson. 2007. Cascading effects of the loss of apex predatory sharks from the coastal ocean. Science 315:1846-1850.
Peterson, C. H., F. J. Fodrie, H. C. Summerson \& S. P. Powers. 2001. Site-specific and density-dependent extinction of prey by schooling rays: generation of a population sink in top-quality habitat for bay scallops. Oecologia 129:349-356.

Sasko, D. 2000. The prey capture behavior of the Atlantic cownose ray, Rhinoptera bonasus. MS thesis, University of South Florida at Tampa.

Sasko, D. E., M. N. Dean, P. J. Motta \& R. E. Hueter. 2006. Prey capture behavior and kinematics of the Atlantic cownose ray, Rhinoptera bonasus. Zoology 109:171-181.

Schwartz, F. J. 1967. Embryology and feeding behavior of the Atlantic cownose ray, Rhinoptera bonasus. Presented at the Association of Island Marine Laboratories of the Caribbean - 7th meeting, Barbados, West Indies.

Smith, J. W. \& J. V. Merriner. 1985. Food habits and feeding behavior of the cownose ray, Rhinoptera bonasus, in lower Chesapeake Bay. Estuaries 8:305-310.

Smith, J. W. \& J. V. Merriner. 1986. Observations on the reproductive biology of the cownose ray, Rhinoptera bonasus, in Chesapeake Bay. Fish Bull. 84:871-877.

Smith, J. W. \& J. V. Merriner. 1987. Age and growth, movements and distribution of the cownose ray, Rhinoptera bonasus, in Chesapeake Bay. Estuaries 10:153-164.

Summers, A. P. 2000. Stiffening the stingray skeleton: an investigation of durophagy in myliobatid stingrays (chondrichthyes, Batoidea, Myliobatidae). J. Morphol. 243:113-126.

Wesson, J. 2009. Cownose ray threats to oyster aquaculture development and shellfish restoration. In: R. Fisher, editor. Regional workshop on cownose ray issues: identifying research and extension needs. Virginia Sea Grant Publication VASG-09-06. pp. 248249. Available at $<$ http://www.vims.edu/adv/fisheries/cownose. html>.

Wetherbee, B. M. \& E. Cortés. 2004. Food consumption and feeding habits. In: Carrier, J., J. Music \& M. Heithaus, editors. Biology of sharks and their relatives. CRC marine biology series. Boca Raton, FL: CRC Press. pp. 225-246. 